\title{
ASPEK BIOLOGI UDANG Metapenaeus conjunctus DI PERAIRAN PEMALANG, JAWA TENGAH \\ Biological Aspects of Metapenaeus conjunctus Shrimp in the Pemalang Water, Central Java
}

\author{
Ahmad Zhafran Siraj, Suradi Wijaya Saputra, Siti Rudiyanti \\ Program Studi Manajemen Sumberdaya Perairan, Departemen Sumberdaya Akuatik \\ Fakultas Perikanan dan Ilmu Kelautan, Universitas Diponegoro \\ J1. Prof. Soedarto, SH, Tembalang, Semarang, Jawa Tengah - 50275, Telp/Fax. +6224 7474698 \\ Email: zhafranahmadsiraj@gmail.com
}

\begin{abstract}
ABSTRAK
Penangkapan udang Metapenaeus conjunctus secara intensif serta tidak berpedoman kepada pendekatan pembangunan berkelanjutan dapat menyebabkan sumber daya $M$. conjunctus terkuras dan juga tingkat eksploitasinya menjadi tidak efisien. Tujuan dari penelitian ini yaitu pengkajian kepada aspek-aspek biologi udang $M$. conjunctus seperti: komposisi hasil tangkapan, struktur ukuran, nisbah kelamin, ukuran pertama kali udang tertangkap ( $\mathrm{L}_{50 \%}$ ), sifat pertumbuhan, faktor kondisi, dan Tingkat Kematangan Gonad. Pelaksanaan penelitian dimulai dari bulan April sampai Juni 2017. Metode penelitian yang digunakan yaitu metode survey. Sampel udang M. conjunctus diambil 1 kali setiap bulan dari Tempat Pelelangan Ikan (TPI) Asemdoyong dan Tanjungsari di Kabupaten Pemalang, Jawa Tengah. Setiap bulan dilakukan satu kali pengambilan sampel. Sampel udang diambil dari total hasil tangkapan salah satu perahu pada setiap TPI. Jumlah sampel udang M. conjunctus yang diteliti yaitu 898 ekor. Hasil penelitian menunjukkan modus panjang karapas udang bulan April 114-129 mm, bulan Mei 82-97 mm, bulan Juni 66-81 mm. Udang M. conjunctus jantan memiliki sifat pertumbuhan isometrik, dan pada udang betina allometrik positif. Nilai faktor kondisi udang jantan adalah 1, sedangkan udang betina 1,15 yang berarti udang betina lebih montok. Ukuran pertama kali tertangkap ( $\left.\mathrm{L}_{50 \%}\right)$ udang jantan 95 dan $92 \mathrm{~mm}$ pada udang betina. Tingkat Kematangan Gonad udang pada bulan April didominasi TKG II 47\% udang jantan dan 50\% udang betina, bulan Mei didominasi TKG I 76\%, bulan Juni didominasi TKG I sebesar $75 \%$. Perbandingan nisbah kelamin udang M. conjunctus jantan dan betina yaitu 1:1,99. Konsep pengelolaan udang $M$. conjunctus di perairan Kabupaten Pemalang penggunaan alat tangkap selektif dengan mesh size yang sesuai, dan operasi penangkapan dilakukan jauh dari bibir pantai. Hal tersebut sesuai dengan prinsip pengelolaan perikanan berkelanjutan.
\end{abstract}

Kata Kunci: Metapenaeus conjunctus; Aspek Biologi; Perairan Pemalang

\section{ABSTRACT}

The intensive catching of Metapenaeus conjunctus shrimp and not guided by the sustainable development approach can cause M. conjunctus resources to be drained and also the level of exploitation becomes inefficient. The purpose of this study is to study the biological aspects of $M$. conjunctus shrimp such as catch composition, size structure, sex ratio, size of the first time the shrimp was caught (L50\%), growth characteristics, condition factors, and Gonad Maturity Level. The research was conducted from April to June 2017. The research method used was the survey method. M. conjunctus shrimp samples were taken once a month from Asemdoyong and Tanjungsari Fish Auction Sites in Pemalang District, Central Java. Every month sampling is done. Shrimp samples were taken from the total catch of one boat at each TPI. The number of samples of M. conjunctus shrimp studied was 898. The results showed the long mode of shrimp carapace in April 114-129 mm, in May 82-97 mm, in June 66-81 mm. Male M. conjunctus shrimp have isometric growth properties, and in allometric positive shrimp. The value of the condition factor of male shrimp is 1 , while female shrimp is 1.15, which means female shrimp is plumper. The first size caught (L50\%) was 95 and 92 mm male shrimp in female shrimp. Maturity Level of shrimp in April was dominated by TKG II 47\% male shrimp and 50\% female shrimp, in May dominated TKG I 76\%, in June dominated TKG I by 75\%. A comparison of male and female M. conjunctus shrimp sex ratio is 1: 1,99. The concept of management of $M$. conjunctus shrimp in Pemalang Regency waters uses selective fishing gear with an appropriate mesh size, and fishing operations are carried out far from the shoreline. This is by following the principles of sustainable fisheries management.

Keywords: Metapenaeus conjunctus; Biological Aspects; Pemalang Water

\section{PENDAHULUAN}

Komoditas udang di perairan Indonesia ditemukan sebanyak 11 (sebelas) jenis udang penaeid yang dapat dikategorikan mempunyai nilai niaga penting. Udang dengan nilai niaga penting tersebut umumnya terdiri dari dua genus yaitu Penaeus dan Metapenaeus, yang tidak hanya terdapat di laut tetapi juga telah banyak dibudi dayakan. Dalam pengusahaan komersil, yang diutamakan adalah Penaeus monodon (udang windu) dan Penaeus mergueinsis 
(udang jerbung), karena kedua jenis ini yang dapat mencapai ukuran besar dan mempunyai pasar yang baik untuk ekspor (Nontji, 2007). Sumber daya perikanan laut Indonesia telah dimanfaatkan secara penuh dapat juga dilihat dari komposisi jenis ikan yang ditangkap. Ikan yang berharga murah dan yang lebih rendah derajatnya dalam rantai makanan mendominasi komposisi produksi ikan. Indikator yang paling jelas pada akhir-akhir ini adalah munculnya ubur-ubur sebagai jenis hayati laut yang tinggi produksinya. Padahal secara biologis, booming (melimpah)-nya uburubur ini adalah indikator bahwa pemangsanya, yaitu ikan-ikan yang lebih besar dan lebih tinggi derajatnya dalam rantai makanan, telah berkurang populasinya karena menjadi sasaran dan target penangkapan nelayan. Melihat indikasiindikasi ini, sebetulnya perairan laut Indonesia dengan sumber daya ikannya telah berada pada kondisi kritis (Nikijuluw, 2002). Hasil kajian bersama Badan Pangan dan Pertania PBB (FAO) dan Bank Dunia tahun 2008 menyebutkan dunia menderita kerugian sekitar US\$ 50 miliar setiap tahun di sektor perikanan laut (perikanan tangkap) akibat keburukan manajemen, inefisiensi, dan kelebihan tangkap (over fishing). Laporan hasil kajian tersebut mengingatkan, jika perikanan laut dikelola dengan benar, maka kerugian tersebut dapat dibalikkan menjadi keuntungan ekonomi keberlanjutan bagi jutaan nelayan dan masyarakat pesisir. Penyebab utama kerugian adalah merosotnya sumber daya ikan. Makin sedikit ikan yang bisa ditangkap, maka makin besar ongkos untuk menjelajah, mencari, dan menangkap ikan (Kordi, 2015).

Tujuan dari penelitian ini adalah untuk mengetahui beberapa aspek biologi udang Metapenaeus conjunctus yang meliputi struktur ukuran, nisbah kelamin, sifat pertumbuhan, faktor kondisi, tingkat kematangan gonad, ukuran pertama kali udang tertangkap, dan melakukan pengkajian pada sistem yang tepat dengan kondisi stok udang di perairan tersebut.

\section{MATERI DAN METODE PENELITIAN}

\section{Materi}

Penelitian udang Metapenaeaus conjunctus yang akan diamati aspek biologinya antara lain yaitu struktur ukuran udang, nisbah kelamin, analisis hubungan panjang berat, faktor kondisi, ukuran pertama tertangkap ( $\mathrm{L}_{50 \%}$ ), ukuran pertama kali matang gonad (Lm), Tingkat Kematangan Gonad (TKG). Udang Metapenaeus conjunctus tersebut diambil dari 2 Tempat Pelelangan Ikan (TPI) di Kabupaten Pemalang, yaitu TPI Tanjungsari dan TPI Asemdoyong.

Metode

Metode pada penelitian ini menggunakan metode survei. Pengambilan sampel udang pada penelitian ini menggunakan metode acak sederhana yaitu dengan cara mengambil udang yang di daratkan pada 2 Tempat Pelelangan Ikan di Kabupaten Pemalang (TPI Tanjungsari dan TPI Asemdoyong). Pengambilan sampel udang Metapenaeus conjunctus dilakukan sebulan sekali selama 3 bulan yaitu antara bulan April - Juni. Penelitian ini menggunakan data primer yang didapatkan dari pengamatan dan pengukuran: identifikasi jenis kelamin dan spesies sampel udang, aspek biologi udang yang berupa panjang, berat, TKG, dan jenis kelamin udang. Data primer meliputi jenis udang, panjang total dan karapas, berat total, jenis kelamin, TKG, serta mesh size. Sampel udang diidentifikasi menggunakan buku referensi Chan (1998), dengan membedakan warna, bentuk tubuh, bentuk alat kelamin jantan dan betina, serta bentuk dan jumlah duri yang terdapat pada rostrum. Setiap spesies juga diambil data panjang (tubuh dan karapasnya), serta beratnya. Panjang tubuh diukur mulai dari ujung rostrum hingga telson. Panjang karapas diukur mulai pangkal karapas depan hingga batas karapa udang dengan badan. Berat tubuh udang diukur menggunakan timbangan elektrik.

\section{Analisis Data \\ Struktur Ukuran}

Struktur ukuran mencerminkan komposisi ukuran udang dan disajikan dalam bentuk grafik histogram. Disamping itu dilakukan perhitungan statistik deskriptif untuk mendapatkan gambaran ukuran minimal, maksimal, modus, dan ukuran pertama kali tertangkap (L50\%).

\section{Identifikasi ukuran panjang pertama kali tertangkap (L50\%)}

Ukuran pertama kali udang tertangkap didapatkan dengan cara memplotkan frekuensi kumulatif dengan setiap panjang udang, sehingga akan diperoleh kurva logistik baku dan titik potong antara kurva dengan 50\% frekuensi kumulatif adalah panjang saat 50\% udang tertangkap (Saputra, 2009). Ukuran udang yang layak tangkap dapat ditentukan dengan terlebih dahulu mencari nilai $\mathrm{L} \infty$, dengan persamaan sebagai berikut:

Dimana :

$$
\boldsymbol{L}_{\infty}=\frac{\boldsymbol{L}_{\text {max }}}{\mathbf{0 , 9 5}}
$$

L $\infty=$ Panjang infinity $\quad ; \quad$ Lmax $=$ Panjang maksimum

Analisis Hubungan Panjang Berat

Menurut Effendie (2002) berat udang dianggap sebagai suatu fungsi dari panjangnya dan hubungan panjang berat ini hampir mengikuti hukum kubik, namun hubungan tersebut sebenarnya tidak demikian karena bentuk tubuh, panjang dan berat udang selalu berubah. Rumus hubungan panjang berat dinyatakan dalam persamaan berikut ini:

$$
\mathbf{W}=\mathbf{a} \mathbf{L}^{\mathbf{b}}
$$

Dimana:

$\mathrm{W}$ : berat $(\mathrm{g}) \mathrm{a}$ : intercept $\quad$; $\quad \mathrm{L}:$ panjang $(\mathrm{mm}) \mathrm{b}$ : slope

\footnotetext{
${ }^{\circledR}$ Copyright by Management of Aquatic Resources (MAQUARES)
} 
Untuk menguji nilai $b=3$ atau $b \neq 3$ dilakukan uji-t (uji parsial), dengan hipotesis:

$\mathrm{H} 0: \mathrm{b}=3$, hubungan panjang dengan berat adalah isometrik.

$\mathrm{H} 1: \mathrm{b} \neq 3$, hubungan panjang dengan berat adalah allometrik, yaitu: allometrik positif, jika $\mathrm{b}>3$ (pertambahan berat lebih cepat daripada pertambahan panjang) dan allometrik negatif, jika $b<3$ (pertambahan panjang lebih cepat daripada pertambahan berat).

\section{Faktor Kondisi}

Cara menghitung nilai faktor kondisi menurut Effendie (2002), yaitu apabila nilai $b=3$ (pola pertumbuhan isometrik), maka perhitungan faktor kondisi digunakan rumus:

$$
K=\frac{10^{5} \mathbf{W}}{L^{3}}
$$

Apabila hasil perhitungan yang didapat adalah angka $b \neq 3$ (pola pertumbuhan alometrik), maka faktor kondisi dihitung dengan rumus:

Keterangan:

$$
K=\frac{W}{a L^{b}}
$$

$\mathrm{K}=$ Faktor Kondisi $; \quad \mathrm{W}=$ Berat $($ gram $) \quad ; \quad \mathrm{L}=$ Panjang total $(\mathrm{mm}) \quad ; \quad$ a dan $\mathrm{b}=$ konstanta yang didapat dari hasil regresi hubungan panjang berat

\section{Tingkat Kematangan Gonad}

Penentuan TKG udang dilakukan dengan cara mengamati morfologi gonad yaitu mengamati bentuk gonad, warna gonad, maupun ukuran gonad. Gonad udang terletak pada bagian dorsal tubuh udang, perkembangannya dapat dlihat secara morfologis tanpa melalui pembedahan apabila karapas tersebut tipis tetapi apabila tidak terlihat dlakukan pembedahan pada bagian dorsal. Perkembangan TKG udang Penaeid dapat diklasifikasikan dalam lima tingkat, menurut Motoh (1981) dalam Saputra et al. (2009), yaitu:

TKG I = Belum matang, ovari tipis, bening dan tidak berwarna;

TKG II = Kematangan awal, ovari membesar, bagian depan dan tengah berkembang;

TKG III = Kematangan lanjut, ovari berwarna hijau muda, dapat dilihat melalui eksoskeleton, bagian depan dan tengah berkembang penuh;

TKG IV = Matang telur, ovari berwarna hijau tua, ovari lebih besar dari sebelumnya;

TKG V = Spent. Ovari lembek dan kisut, telur sudah dilepaskan, biasanya badan udang terasa lembek dan Nisbah Kelamin rongga bagian atas abdomen kosong.

Untuk mengetahui perbandingan kelamin udang jantan dan udang betina dilakukan uji Chi-Kuadrat, yaitu :

$$
X^{2}=\frac{\sum(f o-f h)^{2}}{f h}
$$

Dimana :

X2 = Chi Kuadrat $;$ fo $=$ Persentase hasil pengamatan $\quad ;$ fh $=$ Persentase yang diharapkan

\section{HASIL DAN PEMBAHASAN}

\section{HASIL}

\section{Komposisi Hasil Tangkapan Udang Penaid}

Komposisi hasil tangkapan udang penaid selama penelitian tersaji pada tabel 1.

Tabel 1. Komposisi Hasil Tangkapan Udang Penaid

\begin{tabular}{lllll}
\hline No. & Jenis Udang & April & Mei & Juni \\
\hline 1 & Metapenaeus conjunctus & 189 & 415 & 294 \\
2 & Metapenaeus barbata & 181 & 107 & - \\
3 & Metapenaeus siluensis & 4 & - & - \\
4 & Metapenaeus tenuipes & - & 32 & 40 \\
5 & Metapenaeus dali & - & - & 1 \\
6 & Metapenaeus ensis & - & - & 12 \\
7 & Penaeus merguensis & 96 & 66 & 5 \\
8 & Penaeus indicus & - & 104 & 96 \\
9 & Penaeus cornuta & - & 2 & - \\
10 & Penaeus coromandelica & - & 1 & 14 \\
11 & Penaeus scuiptilis & - & 1 & 1 \\
12 & Penaeus moyebi & - & 20 & - \\
13 & Atypopenaeus stenodactylus & 4 & - & - \\
14 & Trachypenaeus longipes & 74 & 59 & - \\
\hline
\end{tabular}

\footnotetext{
${ }^{\circledR}$ Copyright by Management of Aquatic Resources (MAQUARES)
} 


\section{Struktur Ukuran Udang M. conjunctus}

Berdasarkan hasil penelitian didapatkan sampel udang M. conjunctus secara keseluruhan sebanyak 898 ekor. Sampel udang yang didapat pada masing-masing bulan yaitu: 189 ekor pada bulan April, 415 ekor pada bulan Mei, dan 294 ekor pada bulan Juni. Struktur ukuran udang M. conjunctus disajikan pada gambar 1.

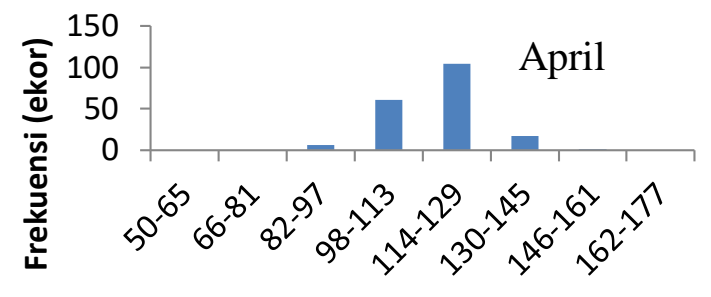

Struktur Ukuran (mm)

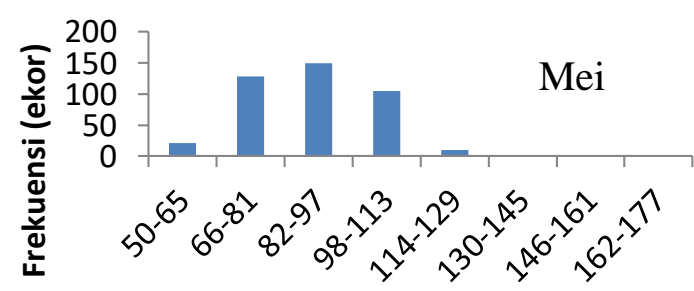

Struktur Ukuran (mm)

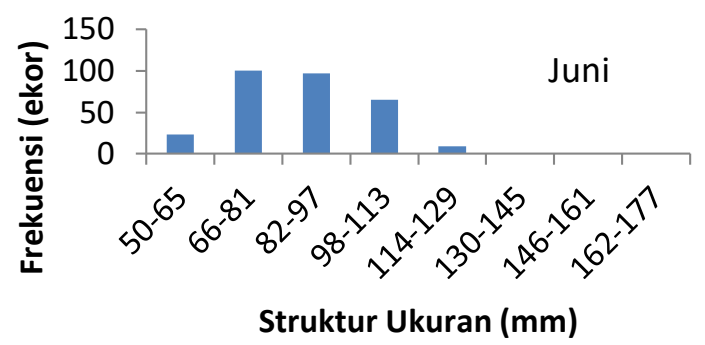

Gambar 1. Histogram Frekuensi Panjang Total Udang M. conjunctus di Perairan Kabupaten Pemalang

\section{Ukuran Pertama Kali Tertangkap (L50\%)}

Pengukuran ukuran pertama kali tertangkap pada udang $M$. conjunctus dilakukan dengan cara pengeplotan panjang karapas berdasarkan kelompok ukuran panjang udang dengan jumlah kumulatif dari udang yang tertangkap. Hal tersebut dapat dilihat pada tabel berikut:

Tabel 2. Ukuran Pertama Kali Tertangkap $\left(\mathrm{L}_{50 \%}\right)$ Udang M. conjunctus di Perairan Kabupaten Pemalang.

\begin{tabular}{lcccc}
\hline Jenis Kelamin & L maks $(\mathrm{mm})$ & $\begin{array}{c}\mathrm{L} \infty \\
(\mathrm{mm})\end{array}$ & $\begin{array}{c}1 / 2 \mathrm{~L} \infty \\
(\mathrm{mm})\end{array}$ & $\begin{array}{c}\mathrm{L}_{50 \%} \\
(\mathrm{~mm})\end{array}$ \\
\hline Jantan & 150 & 157.895 & 78.9474 & 95 \\
Betina & 130 & 136.842 & 68.4211 & 92 \\
\hline
\end{tabular}

Hasil yang didapatkan dari perhitungan ukuran pertama kali tertangkap di atas dapat digambarkan dalam bentuk kurva sesuai dengan Gambar 2.

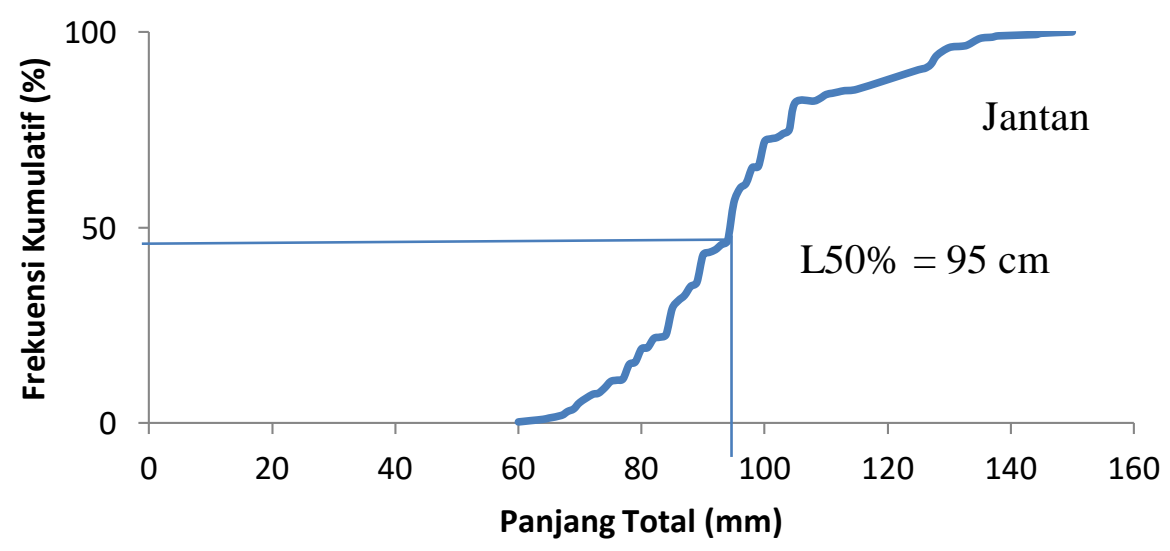

${ }^{\circledR}$ Copyright by Management of Aquatic Resources (MAQUARES) 


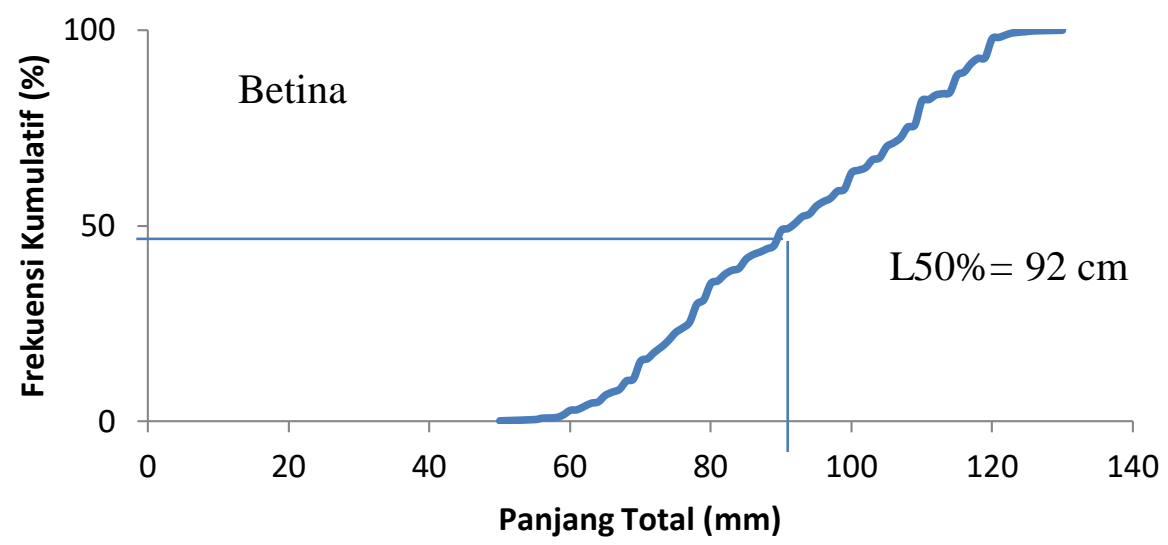

Gambar 2. Kurva Ukuran Pertama Kali Tertangkap Udang M. conjunctus di Perairan Kabupaten Pemalang

Tabel 2. Hubungan Panjang dan Bobot Udang M. conjunctus di Perairan Pemalang Bulan April-Juni 2017.

\begin{tabular}{|c|c|c|}
\hline Parameter & Jantan & Betina \\
\hline $\mathrm{N}$ & 300 & 598 \\
\hline $\mathrm{a}$ & $5.32 \times 10^{-6}$ & $3.33 \times 10^{-6}$ \\
\hline b & 3.07425636 & 3.185061557 \\
\hline Panjang total (mm) & 130 & 150 \\
\hline $\begin{array}{l}\mathrm{W}=\mathrm{aL}^{\mathrm{b}} \\
\mathrm{R}^{2} \\
\text { Sifat pertumbuhan }\end{array}$ & $\begin{array}{c}5.32 \times 10^{-6} \mathrm{~L}^{3,07} \\
0.93 \\
\text { isometrik } \\
\end{array}$ & $\begin{array}{c}3.33 \times 10^{-6} \mathrm{~L}^{3,18} \\
0.94 \\
\text { allometrik positif }\end{array}$ \\
\hline
\end{tabular}
pada Gambar 3.

Grafik hubungan panjang berat udang M. conjunctus dari bulan April-Mei 2017 di perairan Pemalang tersaji

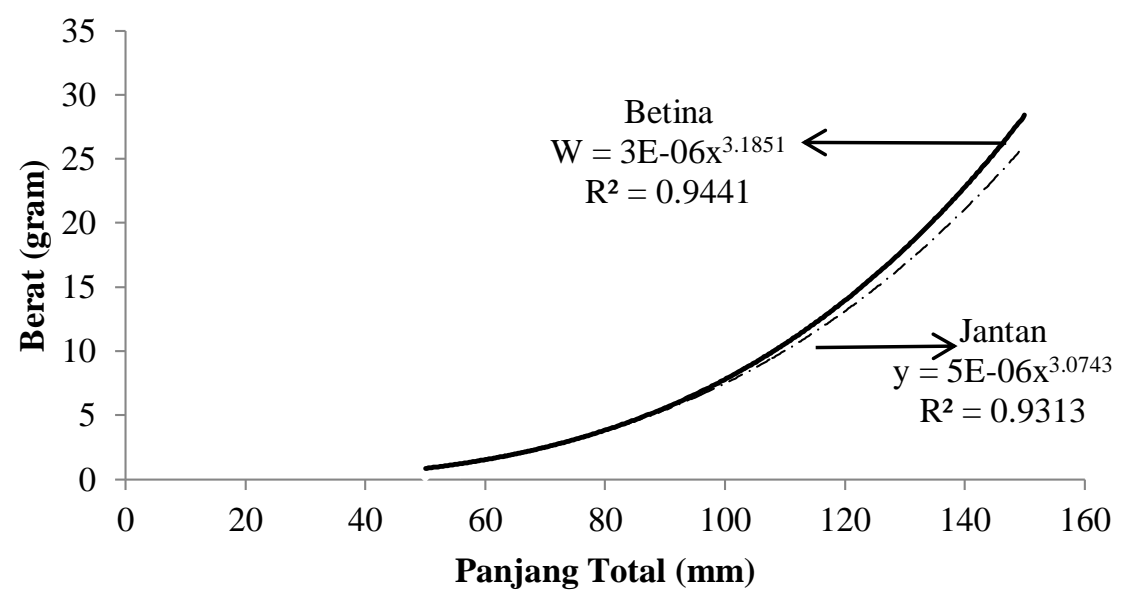

Gambar 3. Kurva Hubungan Panjang Berat Udang M. conjunctus

\section{Faktor Kondisi}

Data yang diperlukan untuk perhitungan faktor kondisi adalah rata-rata panjang total dan rata-rata berat udang selama penelitian. Hasil perhitungan faktor kondisi udang M. conjunctus di perairan Kabupaten Pemalang pada bulan April-Juni 2017 tersaji pada Tabel 3.

Tabel 3. Perhitungan Faktor Kondisi Udang M. conjunctus di perairan Kabupaten Pemalang bulan April-Juni 2017.

\begin{tabular}{lcc}
\hline \multicolumn{1}{c}{ Parameter } & Jantan & Betina \\
\hline $\mathrm{N}$ & 300 & 598 \\
Kisaran Panjang Total (mm) & $60-150$ & $50-130$ \\
Rata-rata Berat (W) (gr) & 7.4571 & 6.907776 \\
Rata-rata Panjang (L) (mm) & 96.02667 & 92.13712 \\
Faktor Kondisi & 1 & 1.15 \\
\hline
\end{tabular}

\footnotetext{
${ }^{\circledR}$ Copyright by Management of Aquatic Resources (MAQUARES)
} 


\section{Tingkat Kematangan Gonad}

Hasil dari pengukuran Tingkat Kematangan Gonad pada udang M. conjunctus di perairan Kabupaten Pemalang pada masa selama penelitian adalah sebagai berikut:

Tabel 6. Tingkat Kematangan Gonad Udang M. conjunctus Bulan April - Juni 2017.

\begin{tabular}{|c|c|c|c|c|c|c|c|c|c|c|}
\hline \multirow{3}{*}{$\begin{array}{l}\text { No } \\
1\end{array}$} & \multirow{3}{*}{$\begin{array}{c}\text { Jenis Kelamin } \\
\text { Jantan }\end{array}$} & \multirow{3}{*}{$\begin{array}{c}\text { Jumlah (ekor) } \\
38\end{array}$} & \multicolumn{8}{|c|}{ Tingkat Kematangan Gonad (April) } \\
\hline & & & \multicolumn{2}{|c|}{ I } & \multicolumn{2}{|c|}{ II } & \multicolumn{2}{|c|}{ III } & \multicolumn{2}{|c|}{ IV } \\
\hline & & & 9 & $24 \%$ & 18 & $47 \%$ & 6 & $16 \%$ & 5 & $13 \%$ \\
\hline 2 & Betina & 92 & 40 & $43 \%$ & 46 & $50 \%$ & 11 & $12 \%$ & 5 & $5 \%$ \\
\hline \multirow{2}{*}{ No } & \multirow{2}{*}{ Jenis Kelamin } & \multirow{2}{*}{ Jumlah (ekor) } & \multicolumn{6}{|c|}{ Tingkat Kematangan Gonad (Mei) } & & \\
\hline & & & & & & & & & \multicolumn{2}{|c|}{ IV } \\
\hline 1 & Jantan & 0 & 0 & $0 \%$ & 0 & $0 \%$ & 0 & $0 \%$ & 0 & $0 \%$ \\
\hline 2 & Betina & 25 & 19 & $76 \%$ & 4 & $16 \%$ & 1 & $4 \%$ & 1 & $4 \%$ \\
\hline \multirow{2}{*}{ No } & \multirow{2}{*}{ Jenis Kelamin } & \multirow{2}{*}{ Jumlah (ekor) } & \multicolumn{6}{|c|}{ Tingkat Kematangan Gonad (Juni) } & & \\
\hline & & & & & & & & & \multicolumn{2}{|c|}{ IV } \\
\hline 1 & Jantan & 0 & 0 & $0 \%$ & 0 & $0 \%$ & 0 & $0 \%$ & 0 & $0 \%$ \\
\hline 2 & Betina & 8 & 6 & $75 \%$ & 2 & $25 \%$ & 0 & $0 \%$ & 0 & $0 \%$ \\
\hline
\end{tabular}

Nisbah Kelamin

Hasil analisis perbandingan antara alat kelamin udang M. conjunctus jantan dan betina tersaji pada gambar 4 . Udang M.conjunctus yang diteliti terdiri dari 300 udang jantan dan 598 udang betina. Nisbah kelamin atau sex ratio dihitung berdasarkan perbandingan antara jumlah udang jantan dan jumlah udang betina, didapatkanlah nilai $1: 1,99$.

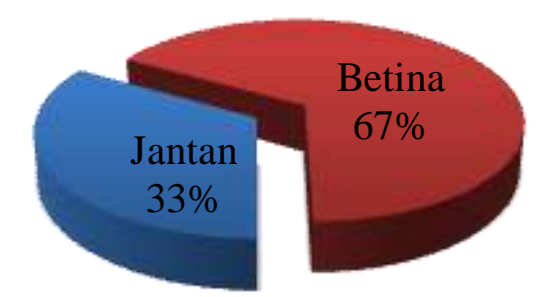

Gambar 4. Diagram Perbandingan Nisbah Kelamin Udang M. conjunctus Jantan dan Betina.

\section{PEMBAHASAN}

\section{Komposisi Hasil Tangkapan Udang Penaid}

Hasil tangkapan udang penaeid di perairan Utara Kabupaten Pemalang didominasi oleh udang M. conjunctus sendiri yang mendapatkan hasil tangkapan sebesar $49 \%$ dari total keseluruhan udang penaeid yang tertangkap. Menurut Sari et al. (2017), Hasil tangkapan udang pada bulan Agustus 2016 sampai bulan Oktober 2016 yang dominan tertangkap di Batang dan Kendal adalah jenis Metapenaeopsis barbata De Haan.1844, Metapenaeus conjunctus Racek dan Dall, 1965, Penaeus merguiensis De Man 1888, Metapenaeus tenuipes Kubo,1949, Trachypenaeus longipes Paulson,1875, dan Penaeus indicus H. Milne Edwards,1837.

Perbedaan komposisi hasil tangkapan tersebut dapat dipengaruhi beberapa hal antara lain perbedaan habitat atau tempat hidup, perbedaan lokasi penelitian dan faktor lingkungan, yang berupa suhu serta ketersediaan makanan (Effendie, 2002). Komposisi hasil tangkapan juga tidak selalu stabil dan cenderung mengalami perubahan sewaktuwaktu. Menurut Ernawati (2007), terjadinya perubahan komposisi hasil tangkapan disebabkan oleh pengaruh musim dan terjadinya fluktuasi jenis atau banyaknya alat tangkap yang beroperasi.

\section{Struktur Ukuran Udang $M$. conjunctus}

Pengamatan struktur ukurang pada udang $M$. conjunctus bermanfaat untuk melihat jumlah frekuensi udang tertangkap dengan perbandingan ukurannya. Hasil dari pengamatan struktur ukuran dapat digunakan sebagai landasan untuk penelitian lainnya. Udang $M$. conjunctus di Kabupaten Pemalang selama masa penelitian menghasilkan struktur ukuran yang berbeda pada setiap bulan. Struktur ukuran dapat dilihat pada frekuensi ukuran udang yang paling banyak 
tertangkap di setiap bulannya atau biasa disebut dengan modus. Sampling pertama bulan April didapatkan modus 114$129 \mathrm{~mm}$. Sampling kedua bulan Mei didapatkan modus 82-97 mm. Sampling ketiga didapatkan modus 66-81 mm.

Udang Metapenaeus conjunctus secara teori menurut Miquel (1982) memiliki panjang tubuh maksimum 143 $\mathrm{mm}$ untuk betina dan $115 \mathrm{~mm}$ untuk udang jantan. Menurut Carpenter dan Niem (1998) dalam Djasmani et al. (2010) udang yang termasuk dalam famili penaeid mempunyai ukuran panjang total yang dapat mencapai $34 \mathrm{~cm}$ atau $340 \mathrm{~mm}$.

\section{Ukuran Pertama Kali Tertangkap (L50\%)}

Berdasarkan data karapas yang didapat dipisahkan antara udang jantan dan betina. Sedangkan pengukuran pada Lmax atau ukuran panjang total pada udang $M$. conjunctus adalah $150 \mathrm{~mm}$ pada udang jantan dan $130 \mathrm{~mm}$ pada udang betina. Selanjutnya dicari nilai L $\infty$ dengan membagi antara nilai Lmax dengan 0,95 . Didapatkanlah nilai $\mathrm{L} \infty$ udang jantan $157.895 \mathrm{~mm}$ dan pada udang betina $136.842 \mathrm{~mm}$. Maka di perhitungan L50\% didapatkanlah nilai $95 \mathrm{~mm}$ pada udang jantan dan $92 \mathrm{~mm}$ pada udang betina. Hasil dari pengukuran L50\% pada udang jantan lebih besar dibandingkan dengan betina diduga karena pergerakan pada udang betina yang lebih lambat.

Menurut Saputra (2013), secara keseluruhan nilai $\left(\mathrm{L}_{50 \%}\right)$ yang didapatkan dari tiap spesies udang Metapenaeus tidak kurang dari setengah nilai L infinity-nya. $L$ infinity ini diinterpretasikan sebagai rata-rata panjang udang pada umur yang sangat tua. Ukuran rata-rata udang Metapenaeus yang tertangkap jaring arad selama penelitian untuk setiap spesies berbeda. Hal ini dapat terjadi akibat pengaruh dari beberapa faktor. Salah satunya adalah faktor fisiologis dari tiap spesies tersebut berbeda, serta kondisi lingkungan seperti ketersediaan makanan, arus, gelombang, kedalaman, suhu, kecerahan, dan lain sebagainya. Selain itu, faktor dari alat tangkap yang digunakan merupakan alat tangkap yang tidak selektif.

\section{Sifat pertumbuhan}

Analisis sifat pertumbuan pada udang $M$. conjunctus menggunakan data perhitungan pada panjang dan bobot udang. Hasil analisis panjang dan bobot udang $M$. conjunctus mendapatkan nilai $\mathrm{W}=5.32 \times 10-6 \mathrm{~L} 3,07$ pada udang jantan dan $\mathrm{W}=3.33 \times 10-6 \mathrm{~L} 3,18$ pada udang betina. Setelah mendapatkan nilai panjang dan bobot, dilakukan pengujian nilai $b$ dengan t-test pada masing-masing jenis kelamin udang. Didapatkan hasil $t$ hitung pada nilai $b$ udang jantan 3.07 yang berarti sifat pertumbuhannya isometrik yaitu pertumbuhan berat udang sebanding dengan panjangnya karena nila $b=3$. Sedangkan udang betina mendapatkan $t$ hitung pada nilai b 3.18 yang berarti sifat pertumbuhannya adalah allometrik positif yaitu pertumbuhan berat udang lebih cepat dibanding panjangnya karena nilai $b>3$.

Menurut Murni (2004), semakin tua umur udang maka pertambahan berat akan lebih besar dibandingkan pertambahan panjangnya, sedangkan pada udang muda pertambahan panjang lebih besar daripada pertambahan berat. Hal tersebut berarti bahwa pada umur tertentu, pertambahan berat akan lebih cepat dari pertambahan panjangnya dan saat mencapai tingkat kedewasaan tertentu, akan mencapai titik dimana udang tidak mengalami perubahan panjang.

\section{Faktor Kondisi}

Perhitungan faktor kondisi udang M. conjunctus di perairan Kabupaten Pemalang pada udang jantan yaitu mendapat nilai 1 yang relatif lebih kecil dibanding udang betina yang mendapatkan nilai faktor kondisi 1,15. Hal ini menandakan bahwa udang M. conjunctus jantan di perairan Kabupaten Pemalang lebih montok dibandingkan dengan udang betina. Menurut Saputra (2008), nilai FK selama penelitian cenderung stabil berada di sekitar nilai satu. Kondisi tersebut mencerminkan bahwa waktu relatif tidak mempengaruhi kecepatan dan keseimbangan pertumbuhan udang. Udang M. conjunctus di perairan Kabupaten Pemalang semuanya memiliki nilai faktor kondisi (Kn) di bawah 2. Hal ini memberikan arti bahwa udang M. conjunctus yang ada di Kabupaten Pemalang kurus atau kurang montok.

Menurut Effendie (2002), kisaran harga Kn antara 2 - 4 berarti udang gemuk, sedangkan pada kisaran 1 - 2 badan udang kurus. Hal ini diduga karena daerah penangkapan nelayan Pemalang merupakan daerah pembesaran, sehingga nilai faktor kondisi pada tiap jenis kelamin udang $M$. conjunctus memiliki nilai $\mathrm{Kn}<2$.

\section{Tingkat Kematangan Gonad}

Berdasarkan identifikasi Tingkat Kematangan Gonad udang M. conjunctus dari bulan April-Juni 2017 didapati nilai TKG berbeda pada setiap bulan. Bulan April didominasi nilai TKG II $41 \%$ udang jantan dan $32 \%$ udang betina. Pada bulan Mei dan Juni didapati nilai TKG dominan 0, hal tersebut karena tidak terlihatnya gonad pada saat dilakukan identifikasi.

Menurut Saputra (2005) sumberdaya udang sekarang telah terjadi lebih tangkap (overfishing), terutama diakibatkan oleh karena lebih tangkap pertumbuhan (growth overfishing). Hal tersebut pada akhinrya akan mengakibatkan terjadinya recruitment overfishing karena tidak cukup tersedianya induk yang memijah, sehingga dapat mengancam kelestarian sumberdaya udang. Kematangan gonad udang dipengaruhi oleh dua faktor yaitu faktor dalam dan luar. Faktor dalam antara lain spesies, umur, dan ukuran, sedangkan faktor luar adalah suhu, arus, dan curah hujan.

\section{Nisbah Kelamin}

Analisis nisbah kelamin (sex ratio) pada udang M. conjunctus selama masa penelitian memiliki perbandingan yang cukup besar yaitu $1: 1,99$. Perbandingan tersebut cukup baik karena jumlah udang betina sebagai penghasil benih

\footnotetext{
${ }^{\circledR}$ Copyright by Management of Aquatic Resources (MAQUARES)
} 
lebih banyak. Menurut Saputra et al. (2009), apabila jantan dan betina seimbang atau betina lebih banyak dapat dikatakan bahwa populasi tersebut masih ideal untuk mempertahankan kelestariannya.

\section{KESIMPULAN}

Kesimpulan yang dapat diberikan dari penelitian ini adalah:

1. Struktur akuran udang Metapenaeus conjunctus selama penelitian adalah: sampling pertama bulan April didapatkan modus 114-129 mm. Sampling kedua bulan Mei didapatkan modus 82-97 mm. Sampling ketiga bulan Juni didapatkan modus $66-81 \mathrm{~mm}$.

2. Ukuran pertama kali tertangkap ( $\mathrm{L}_{50 \%}$ ) udang $M$. conjunctus jantan $95 \mathrm{~mm}$, dan pada udang betina $92 \mathrm{~mm}$.

3. Pertumbuhan udang M. conjunctus jantan selama masa penilitian bersifat isometrik, sedangkan pertumbuhan udang betina bersifat allometrik positif.

4. Faktor kondisi udang jantan mendapatkan nilai 1, dan pada udang betina 1.15 yang artinya udang betina lebih montok.

5. Udang M. conjunctus di Kabupaten Pemalang memiliki Tingkat Kematangan Gonad (TKG) II dominan pada bulan April, dominan 0 pada bulan Mei dan Juni.

6. Perbandingan nisbah kelamin udang $M$.conjunctus jantan dan betina yaitu $1: 1,99$ yang mengindikasikan perbandingannya ideal.

\section{DAFTAR PUSTAKA}

Chan TY. 1998. Shrimps and Prawns. Di dalam: Carpenter KE, VH Niem. Ed. The Living Marine Resources of the Western Central Pasific. Vol 2 Cephalopods, Crustaceans, Holothurians and Sharks. Food and Agriculture Organization of the United Nations Rome. Dall W, B. J. Hill, P. C. Rothlesberg, D. J. Sharples.

Djasmani, S. S., Djumanto, S. T. Sari. 2010. Komposisi Udang Hasil Tangkapan Jaring Ciker pada Nelayan Tegalkamulyan di Kabupaten Cilacap. Jurnal Perikanan. 7 (2) : 64-71

Effendie, M. I. 2002. Biologi Perikanan. Yayasan Pustaka Nusantara. Yogyakarta. $163 \mathrm{hlm}$.

Ernawati, T. 2007. Distribusi dan komposisi jenis ikan demersal yang tertangkap trawl pada musim barat di perairan Utara Jawa Tengah. Jurnal Iktiologi Indonesia, 7(1) : 41-45.

Kordi, K.M.G.H. 2015. Pengelolaan Perikanan Indonesia. Pustaka Baru Express. Yogyakarta.

Miquel, J. C. E. 1982. Le Genre Metapenaeus (Crustasea, Penaeidae) : Taxonomie, Biologie Et Peches Mondiales. 133 hlm.

Murni, I. 2004. Kajian Tingkat Kematangan Gonad Udang Galah di Muara Sungai Kapuas Pontianak, Kalimantan Barat. Sekolah Pascasarjana. Institut Pertanian Bogor. Bogor.

Nikijuluw, 2002. Rezim Pengelolaan Sumberdaya Perikanan. Kerjasama P3R dengan PT Pustaka Cidesindo. Jakarta.

Nontji, A. 2007. Laut Nusantara (Edisi revisi). Penerbit Djambatan. Jakarta.

Saputra, S. W., 2005. Dinamika populasi udang jari (Metapenaeus elegans de Man 1907) dan pengelolaannya di laguna segara anakan cilacap Jawa tengah. Tesis. Bogor: Pascasarjana Institut Pertanian Bogor.

2008. Distribusi dan Ruaya Udang Jari (Metapenaeus elegans de Man 1907) di Laguna Segara Anakan Cilacap Jawa Tengah. Jurnal Saintek Perikanan. Vol. 3(2): 1-8.

. 2009. Dinamika Populasi ikan. Universitas Diponegoro. 199 Hlm.

, P. Soedarsono dan G.A. Sulistyawati. 2009. Beberapa Aspek Biologi Ikan Kuniran (Upeneus spp.) di Perairan Demak. J. Saintek Perikanan. 5(1):1-6.

., A. Solichin, W. Rizkiyana. 2013. Keragaman Jenis dan Beberapa Aspek Biologi Udang Metapenaeus di Perairan Cilacap, Jawa Tengah. Journal of Management of Aquatic Resources. 2 (3) : 37-46.

Sari, K. D., S. W. Saputra, A. Solichin. 2017. Aspek Biologi Udang Jerbung (Penaeus merguiensis de Man, 1888) di Perairan Kendal, Jawa Tengah. Diponegoro Journal Of Maquares, 6(2) : 1-9. 